Original scientific paper

\title{
RIGOROUS DYNAMIC SIMULATION OF A DEHYDRATION AND DESALTING CRUDE OIL UNIT USING ASPEN HYSYS ${ }^{\circledR}$
}

\author{
Sotelo, C.*; Favela-Contreras, A.,\#; Ramirez-Mendoza, R. A..; Beltran-Carbajal, F. ${ }^{* * *}$; \\ Cruz, E. ${ }^{* *} \&$ Sotelo, D.* \\ * Tecnologico de Monterrey, Escuela de Ingenieria y Ciencias, Monterrey, México \\ ** PEMEX, Exploración y Producción, Ciudad del Carmen, México \\ **** Universidad Autónoma Metropolitana, Unidad Azcapotzalco, Departamento de Energía, \\ Ciudad de México, México
}

E-Mail: carlos.sotelo@tec.mx, antonio.favela@tec.mx, ricardo.ramirez@tec.mx, fbeltran@azc.uam.mx, ezequiel.cruz@pemex.com, david.sotelo@tec.mx ( ${ }^{\#}$ Corresponding author)

\begin{abstract}
Considering that two-thirds of world oil production receive a treatment after extraction to remove water and salt contents, one of the most important processes to avoid operational problems in refinery plants corresponds to the dehydration and desalting unit. Here, live crude oil at high temperatures and pressures is processed and stabilized. Henceforth, to optimize these petrochemical plants, simulation has become an important tool. Nevertheless, due to its sequential modular nature related with mass/energy recycle steam circuits, the modelling and simulation of this process is commonly simplified. Thus, to reproduce the process behaviour of the unit under operating conditions and identify its effect on the final product, this work presents an unpublished rigorous dynamic simulation-based procedure of a complete real dehydration and desalting process using Aspen HYSYS ${ }^{\circledR}$. Different pieces of equipment are carefully designed based on literature review, and a specially tailored procedure is proposed to estimate the water and salt contents at any stage of the plant. Finally, to validate the simulation, the accuracy of the main flows and chemical contents along the process are compared with actual data.

(Received in October 2020, accepted in February 2021. This paper was with the authors 1 month for 1 revision.)
\end{abstract}

Key Words: Dehydration Unit, Desalting Unit, Modelling, Simulation, Aspen HYSYS ${ }^{\circledR}$

\section{INTRODUCTION}

The generation of wastes that result in the oil industry is an inevitable consequence of the processing of crude oil. The dehydration and desalting crude oil plant, where oil-water emulsions accompanied by inorganic salts are removed from the crude oil, represents the main source of wastes [1]. The sequential modular nature of the process possesses a big challenge to conduct a deep analysis of the unit operation to overhead this environmental problem [2]. Henceforth, to optimize these petrochemical plants, simulation has become an important tool. Nevertheless, steady state simulation modelling in petrochemical process simulators environment is fairly standard today, and only little is known about the dynamic simulation in the research field [3]. Some steady state modelling and simulations of dehydration and desalting crude oil plants described in the literature [4-8]. In [4], a modified crude oil desalting unit to improve the dehydration efficiency is presented. Moreover, a characterization and modelling of a crude oil desalting plant by a statistically designed approach has been addressed in [5]. Furthermore, a new model to eliminate salts from a Sarir crude oil in Libya is presented in [6]. In $[7,8]$, a desalting drum from a South Oil Company in Iran is modelled based on the electric field. However, petrochemical units do not operate in steady state; thus, these models are of limited usefulness in studying routing operation [9]. On the other hand, [10,11] present a dynamic modelling simulation. In [10] a hierarchical structure for modelling a dewatering and desalting plant for the Eastern Siberia oilfield is presented and in [11] a desalting process in a petroleum refinery located at Bangalore, India is simulated. Nevertheless, these dynamic process simulations are simplified which do not represent a realistic dehydration and desalting 
crude oil unit. Thus, considering the lack of proper simulation, this work presents a rigorous and accurate modelling simulation of a complete dehydration and desalting crude oil process using Aspen HYSYS ${ }^{\mathbb{R}}$ environment in dynamic mode. Hence, design and sizing equipment is described in detail and a recursive algorithm to estimate the water and salt contents at any stage of the plant is proposed. Finally, the simulation results are compared with actual data.

This paper is structured as follows: Section 2 presents a brief description of the process. In Section 3, the modelling equations that rigorously capture the full off-design characteristics of the plant components in Aspen HYSYS ${ }^{\circledR}$ are explained in detail. Moreover, a systematic procedure to estimate the water and salt contents in the crude oil is described. In Section 4, the simulation results are compared with actual data taken from a Mexican crude oil dehydration and desalting plant. Finally, conclusions and future research works are presented in Section 5.

\section{PROCESS DESCRIPTION}

Offshore crude oil is accompanied by a considerable amount of brine causing corrosion of lines, fouling and catalyst poisoning in the crude oil refining industry [12,13]. To avoid these operating problems, a preliminary crude oil treatment is required. The process commonly used takes place in a dehydration and desalting crude oil plant (Fig. 1). Here, six hundred Mbbl/day (thousands of barrels per day) are feed into the dehydration stage where the gun barrel TV-5008 tank is used to settle out the liquid drops by gravity into the water management stage. Moreover, the oil outlet of the holding vessel is pumped to a pre-heat process carried out by the heater EA-3201. Then, the viscosity of the continuous oil phase is decreased and the density difference between the brine and crude oil is increased. After that, fresh water is supplied to the steam and then fed into the FA-3020 tank to obtain light hydrocarbons at the top. Furthermore, the crude oil is taken from the bottom of the FA-3020 reservoir and put into the desalting stage where the gun barrel TV-5006 tank carries out a second water extraction. Thus, the remnant brine is reinjected back into the process for pressure maintenance and enhanced recovery produced water. Additionally, the crude oil feed is pumped to a heat exchanger EA-3200 to decrease its operating temperature. As a result, crude oil should meet refining specifications in salinity and water content, $50 \mathrm{PTB}-0.5 \% \mathrm{H}_{2} \mathrm{O}$, respectively.

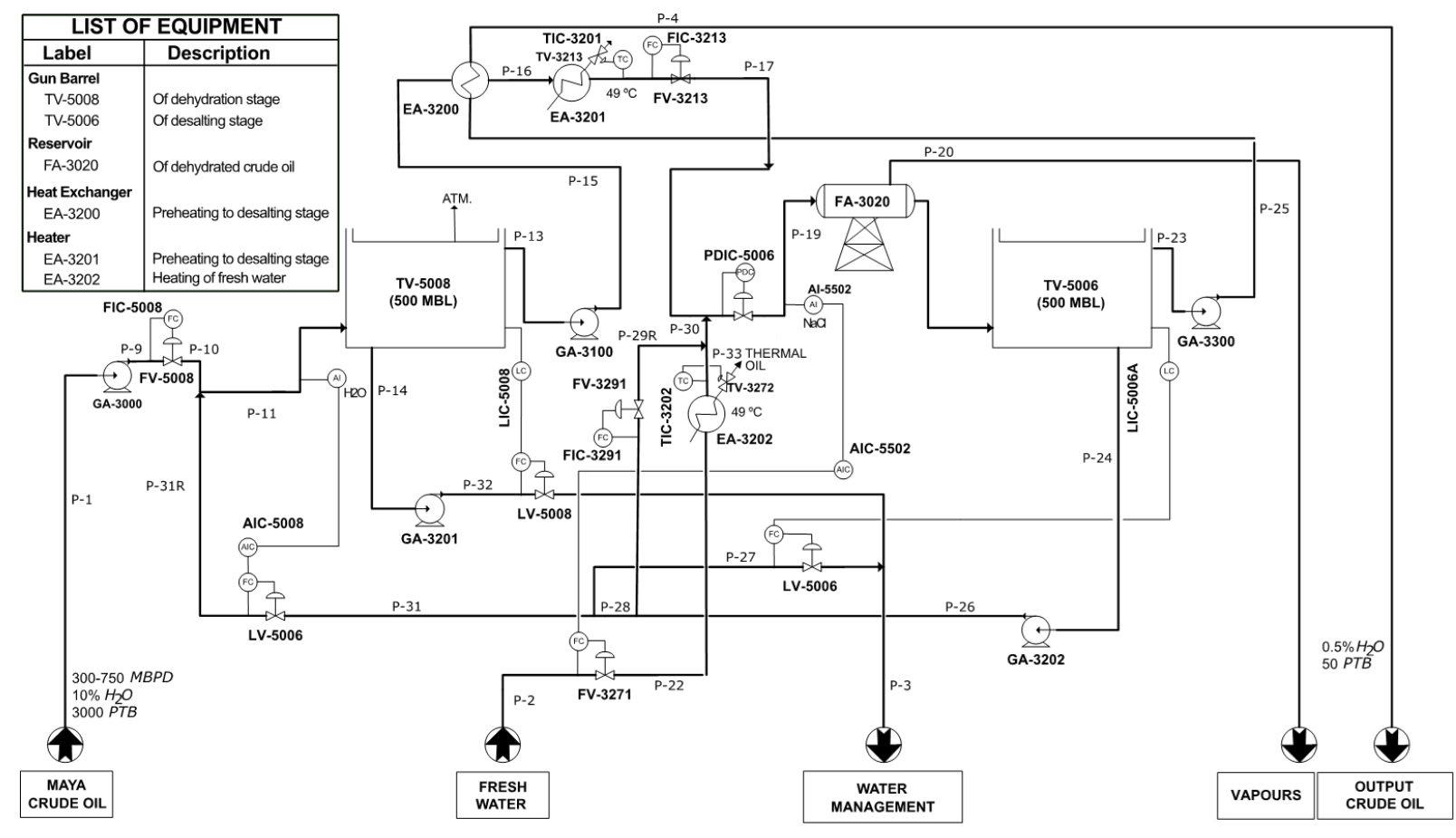

Figure 1: Process flowsheet. 


\section{MODELLING AND SIMULATION}

The dehydration and desalting crude oil plant is built-up using Aspen HYSYS ${ }^{\circledR}$. As in previous simulated research works on gas oil and refining processes [14-17], the plant components are rigorously designed according to its operating conditions and theoretical data reported in the literature field. Hence, as in [18, 19], Peng-Robinson (PR) fluid package is used as database to generate the thermodynamic equilibrium of the process [20].

\subsection{Steady state modelling}

The characteristics of crude oil are strongly related with the designing and operation of every equipment in petrochemical plants [21]. To provide the input feed for the dehydration and desalting plant, a characterized Mexican heavy crude oil and a specific amount of water and salinity are inlet into a Mixer. In Table I the petroleum properties such as crude oil fractions, sulphur content, viscosity, density, octane number and API (American Petroleum Institute) gravity, which ranges from 10 to $66.3^{\circ}$, are set according to actual data [22].

Table I: Characterization of the Mexican heavy crude oil [22].

\begin{tabular}{|c|c|c|c|}
\hline Component & Mole fraction & Molecular weight & ${ }^{\circ} \mathrm{API} 60^{\circ} \mathrm{F}$ \\
\hline Water $\left(\mathrm{H}_{2} \mathrm{O}\right)$ & 0.6700 & 18 & \\
\hline Hydrogen Sulfide $\left(\mathrm{H}_{2} \mathrm{~S}\right)$ & 0.0004 & 65 & \\
\hline Carbon dioxide $\left(\mathrm{CO}_{2}\right)$ & 0.0001 & 44 & \\
\hline Nitrogen $\left(\mathrm{N}_{2}\right)$ & 0.0000 & 28 & \\
\hline Methane $\left(\mathrm{CH}_{4}\right)$ & 0.0003 & 16 & \\
\hline Ethane $\left(\mathrm{C}_{2} \mathrm{H}_{6}\right)$ & 0.0018 & 30 & \\
\hline Propane $\left(\mathrm{C}_{3} \mathrm{H}_{8}\right)$ & 0.0054 & 44 & \\
\hline i-Butane $\mathrm{HC}\left(\mathrm{CH}_{3}\right)_{3}$ & 0.0019 & 58 & \\
\hline Butane $\left(\mathrm{C}_{4} \mathrm{H}_{10}\right)$ & 0.0065 & 58 & \\
\hline i-Pentane $\mathrm{CH}\left(\mathrm{CH}_{3}\right)_{2}\left(\mathrm{C}_{2} \mathrm{H}_{5}\right)$ & 0.0049 & 72 & \\
\hline Pentane $\left(\mathrm{C}_{5} \mathrm{H}_{12}\right)$ & 0.0079 & 72 & \\
\hline Hexane $\left(\mathrm{C}_{6} \mathrm{H}_{14}\right)$ & 0.0143 & 86 & \\
\hline Maya_1 & 0.0156 & 99 & 66.3 \\
\hline Maya_2 & 0.0222 & 110 & 59.1 \\
\hline Maya_3 & 0.0186 & 125 & 53.6 \\
\hline Maya_4 & 0.0186 & 138 & 50.1 \\
\hline Maya_5 & 0.0167 & 154 & 47.2 \\
\hline Maya_6 & 0.0094 & 165 & 42.8 \\
\hline Maya_7 & 0.0095 & 180 & 41.5 \\
\hline Maya_8 & 0.0188 & 196 & 37.2 \\
\hline Maya_9 & 0.0093 & 208 & 33.9 \\
\hline Maya_10 & 0.0151 & 222 & 32.7 \\
\hline Maya_11 & 0.0088 & 234 & 30.5 \\
\hline Maya_12 & 0.0061 & 245 & 28.2 \\
\hline Maya_13 & 0.1177 & 635 & 10.0 \\
\hline Salt $(\mathrm{NaCl})$ & 0.0000 & 58.44 & \\
\hline
\end{tabular}

The gun barrel tanks TV-5008, FA-3020 and TV-5006 corresponds to the most important units in the dehydration and desalting process. The TV-5008 and TV-5006 vessels are modelled as three phase flat cylinder containers operating at a pressure of 94.05 and $111.89 \mathrm{kPa}$, respectively. As they are vertically oriented, the resulting large surface area helps the vapour - liquid separation [23]. On the other hand, operating at a pressure of $108.36 \mathrm{kPa}$, the FA-3020 is modelled as a horizontal two phases flat cylinder container to reduce the turbulence and large volumes of gas and liquids (see Table II). 
Table II: Flat cylinder vessels.

\begin{tabular}{|c|c|c|c|c|c|}
\hline Vessel & $\begin{array}{c}\text { Liquid rate } \\
(\text { barrels/day) }\end{array}$ & $\begin{array}{c}\text { Vapour rate } \\
\left(\mathrm{m}^{3} / \mathrm{s}\right)\end{array}$ & $\begin{array}{c}\text { Liquid density } \\
\left(\mathrm{g} / \mathrm{cm}^{3}\right)\end{array}$ & $\begin{array}{c}\text { Gas density } \\
\left(\mathrm{g} / \mathrm{cm}^{3}\right)\end{array}$ & $\begin{array}{c}\text { Capacity } \\
(\mathrm{bbl})\end{array}$ \\
\hline TV-5008 & 3.200 & 2.5575 & 0.92 & 0.0013 & $526,996.5$ \\
\hline FA-3020 & 6.248 & 4.9230 & 0.899 & 0.002 & $1,283.6686$ \\
\hline TV-5006 & 1.829 & 1.5335 & 0.90 & 0.0016 & $526,996.5$ \\
\hline
\end{tabular}

To produce smooth output flow and operate safely against partially closed control valves, the pump systems are modelled by centrifugal pumps operating with an adiabatic efficiency of $75 \%$. This is the most common type of pump used in field handling of crude oil [24]. Hence, to ensure process design specifications are met, the inlet and outlet pressures (pressure drop, or $\Delta P)$ and the duty for each pump along the process are specified in Table III.

Table III: Pump design.

\begin{tabular}{|c|c|c|}
\hline Pump & $\boldsymbol{\Delta P}(\mathrm{kPa})$ & Duty (hp) \\
\hline GA-3000 & 349.8 & 585.4 \\
\hline GA-3100 & 478.3 & 500.8 \\
\hline GA-3201 & 378.0 & 130.3 \\
\hline GA-3300 & 519.7 & 551.6 \\
\hline GA-3202 & 361.4 & 37.33 \\
\hline
\end{tabular}

The pre-heat process is modelled by the heater EA-3201. Here, using thermal oil at $200^{\circ} \mathrm{C}$ and $392.266 \mathrm{kPa}$ as primary energy source, the operating temperature of the crude oil obtained from the dehydration stage is increased up to $49{ }^{\circ} \mathrm{C}$. Similarly, to increase up to $49{ }^{\circ} \mathrm{C}$ the operating temperature of the recycled water steam from the desalting stage, the heater EA-3202 is simulated (see Table IV). Finally, to decrease the desalted crude oil operating temperature to $45^{\circ} \mathrm{C}$, the heat exchanger EA-32000 with a volume of $14.16 \mathrm{~m}^{3}$ and a duty of $1.98 \times 10^{7} \mathrm{Btu} / \mathrm{hr}$ is modelled as a heat exchanger shell and tube type. This is the most widely heat exchanger used in oil refineries and chemical plants [25].

Table IV: Heaters design.

\begin{tabular}{|c|c|c|c|}
\hline Heater & Volume $\left(\mathrm{m}^{3}\right)$ & $\boldsymbol{\Delta P}(\mathrm{kPa})$ & Duty $(\mathrm{Btu} / \mathrm{hr})$ \\
\hline EA-3201 & 20 & 6.57 & $6.29 \times 107$ \\
\hline EA-3202 & 14.16 & 98.06 & $8.26 \times 106$ \\
\hline
\end{tabular}

\subsection{Dynamic state modelling}

Before steady-state simulation is exported, a proper design of the gun barrels tanks is prerequisite to get an efficient purification of aqueous crude oil [26, 27]. As in [28], the tray sizing tool available in Aspen HYSYS ${ }^{\circledR}$ is used to calculate the require data. The sizing parameters set according to [22] is shown in Table $\mathrm{V}$.

Table V: Geometric parameters for vessels.

\begin{tabular}{|c|c|c|c|c|c|c|}
\hline Vessel & $\begin{array}{c}\text { Diameter } \\
(\mathrm{m})\end{array}$ & $\begin{array}{c}\text { Height/Length } \\
(\mathrm{m})\end{array}$ & $\begin{array}{c}\text { Inlet feed } \\
(\mathrm{m})\end{array}$ & $\begin{array}{c}\text { Oil outlet } \\
(\mathrm{m})\end{array}$ & $\begin{array}{c}\text { Water outlet } \\
(\mathrm{m})\end{array}$ & $\begin{array}{c}\text { Gas outlet } \\
(\mathrm{m})\end{array}$ \\
\hline TV-5008 & 85.3 & 14.66 & 13.739 & 11.2 & 0.3 & 14.63 \\
\hline FA-3020 & 4.305 & 14.021 & 4.305 & 0 & NA & 4.305 \\
\hline TV-5006 & 85.3 & 14.66 & 13.739 & 11.2 & 0.3 & 14.63 \\
\hline
\end{tabular}

Additionally, to operate in Aspen HYSYS ${ }^{\circledR}$ dynamic mode, the dynamic requirements for vessels (Fig. 2) shown in Table VI are calculated based on [24, 25, 29, 30]. 


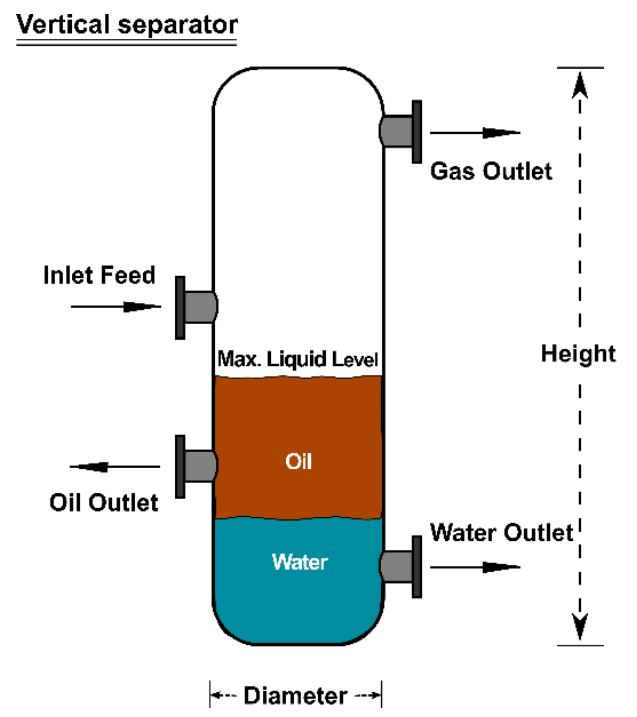

Horizontal separator

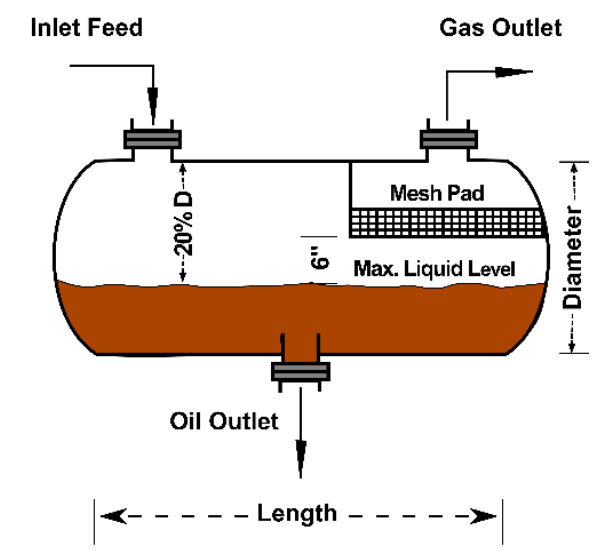

Figure 2: Vessel parameters.

Table VI: Dynamic requirements for vessels.

\begin{tabular}{|c|c|c|c|}
\hline Vessel & Mesh pad $(\mathrm{m})$ & Max. liquid level $(\mathrm{m})$ & Liquid level $(\mathrm{m})$ \\
\hline TV-5008 & NA & 13.4154 & 13.0049 \\
\hline FA-3020 & 3.5964 & 3.444 & 2.455 \\
\hline TV-5006 & NA & 13.4154 & 13.0049 \\
\hline
\end{tabular}

After a detailed modelling is carried out, the input/output relationships that fully accept the interaction of the sub-units are considered to obtain a proper dynamic simulation [31, 32]. Fig. 3 shows the simulated dehydration and desalting plant under a conventional control structure. Here, controllers are tuned by Ziegler-Nichols and Auto-Tune Variation techniques.

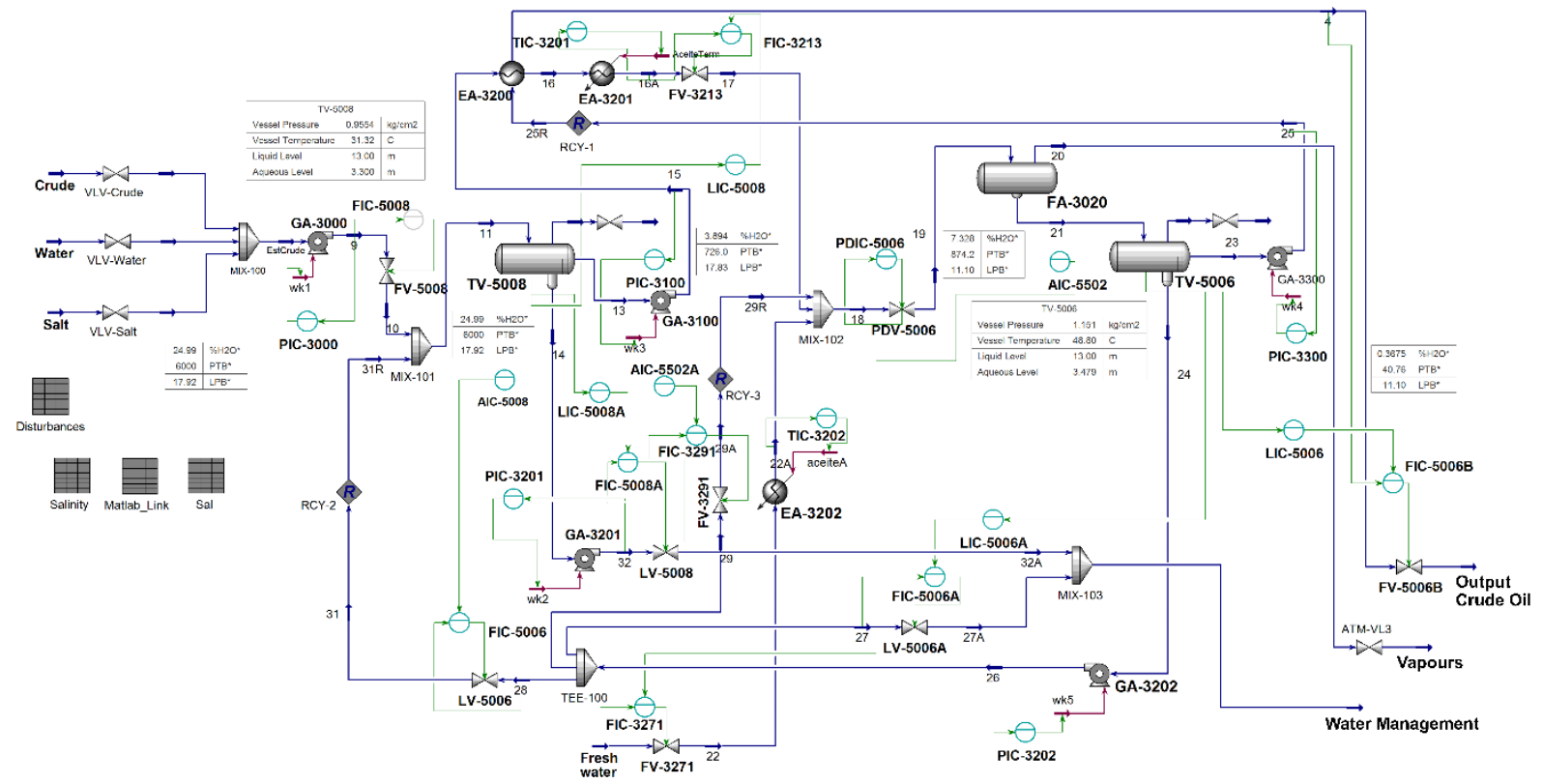

Figure 3: Simulated dehydration and desalting plant.

\subsection{Simulation procedure to estimate water and salt content}

In the absence of solid light crystals, the salt content of the crude expressed as pounds of salt per thousand barrels $(P T B)$ is directly related to the volume percentage of water $\left(\% \mathrm{H}_{2} \mathrm{O}\right)$ and the brine concentration denoted by parts per million ( $p p m)$. Thus, using the conventional basis 
of 1000 barrels $(b b l)$ of clean crude, the salt content at any stage in the dehydration/desalting crude oil plant can be obtained, Eq. (1):

$$
\text { PTB }=1000 \frac{\% \mathrm{H}_{2} \mathrm{O}}{100-\% \mathrm{H}_{2} \mathrm{O}}\left(350 * S G_{\text {Brine }}\right) \frac{p p m}{1 \times 10^{6}}
$$

where $S G_{\text {Brine }}$ is the specific gravity of the brine solution, and $\% \mathrm{H}_{2} \mathrm{O}$ is obtained by Eq. (2):

$$
\% \mathrm{H}_{2} \mathrm{O}=\frac{\text { Liq Vol Flow (Aqueous phase)[barrels/day] }}{\text { Liq Vol Flow (Overall) }[\text { barrels/day] }} \times 100
$$

Additionally, the ppm (milligrams of solute per liters of solution) is computed, Eq. (3):

$$
\text { ppm }=24[\mathrm{hr} / \text { day }] \frac{\text { Salt composition }[\mathrm{lb} / \mathrm{hr}]}{\text { Liq Vol Flow (Aqueous phase) [barrels/day }]} \frac{453592[\mathrm{mg} / \mathrm{lb}]}{158.987[\mathrm{l} / \mathrm{barrel}]}
$$

Therefore, defining the element $z_{n}^{r}$, where: $z$ is the salt composition, $n$ corresponds to the line or the gun barrel number of analysis and $r$ stands for the recursive stage, the brine concentration $(\mathrm{ppm})$ can be estimated using the sequential modular simulator Aspen HYSYS ${ }^{\circledR}$ $[14,17]$. However, in the dehydration and desalting plant, the stream circuits involve mass/energy recycle modules requiring a simultaneous rather than a sequential solution. Hence, in Fig. 4, the values of the outlet stream conditions are assumed to solve the flowsheet sequentially around the recycles modules. Herein, based on the tearing streams compositions, a simulation procedure to estimate the water and salts contents in crude oil is presented.

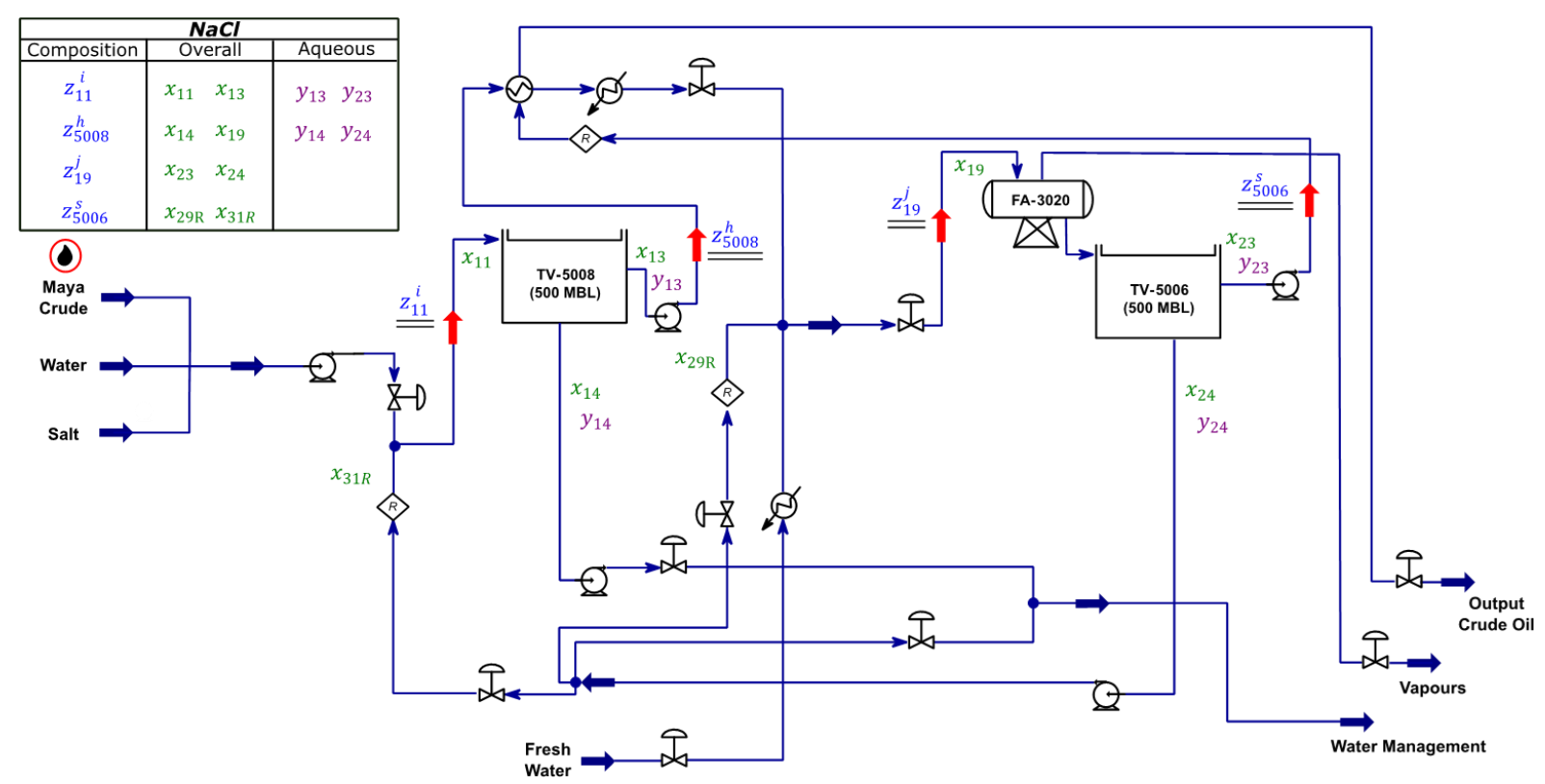

Figure 4: Analysis of salt composition.

Based on the differences between the inlet and outlet streams conditions, the outlet stream is updated iteratively until the inlet stream match the corresponding output conditions within the tolerances specified in the recycle module. The following sets are established:

$$
\begin{array}{ll}
\mathcal{X}=\left\{x_{11}, x_{31 R}, x_{24}, x_{23}, x_{19}, x_{29 R}, x_{13}, x_{14}\right\}, & \mathcal{Y}=\left\{y_{23}, y_{24}, y_{13}, y_{14}\right\}, \\
z=\left\{z_{11}^{i}, z_{5006}^{s}, z_{19}^{j}, z_{5008}^{h}, z_{11}^{i-1}, z_{5006}^{s-1}, z_{j-1}, z_{s-2}, z_{h-1}\right\}, & \mathcal{K}=\left\{k_{19}^{s}, k_{13}^{h^{\prime}}, k_{11}^{h}, k_{h^{\prime}-1}, k_{s-1}, k_{s-2}\right\}
\end{array}
$$

where $\mathcal{X}$ is the set of overall $\mathrm{NaCl}$ concentrations (aqueous, liquid and vapor phases), $\mathcal{Y}$ is the set of aqueous $\mathrm{NaCl}$ compositions, $\mathcal{Z}$ is the set of recursive salt concentrations and $\mathcal{K}$ is the set of factors which relates the recursive concentration equations with the overall $\mathrm{NaCl}$ of the line.

The salt composition at the input of the dehydration stage (line 11) is estimated, Eq. (4): 


$$
z_{11}^{i}=\left(x_{11}-x_{31 R}\right)+x_{31 R}\left(\frac{z_{5006}^{S}}{x_{24}}\right)
$$

where $z_{5006}^{S}=k_{19}^{S} x_{24}\left(\frac{x_{23}+x_{24}}{y_{23}+y_{24}}\right)$ is the salt composition at the output of TV-5006 and $k_{19}^{s}=\frac{z_{19}^{j}}{x_{19}}$ is the factor which relates the recursive concentration equation with the overall $\mathrm{NaCl}$ in line 19 .

Considering that $z_{19}^{j}$, the salt composition at the input of the desalting stage (line 19), can be expressed as below, Eq. (5):

$$
z_{19}^{j}=k_{13}^{h^{\prime}}\left(x_{19}-x_{29 R}\right)+x_{29 R}\left(\frac{z_{5006}^{S}}{x_{24}}\right)
$$

where $k_{13}^{h^{\prime}}=\frac{z_{5008}^{h}}{x_{13}}$, in which $z_{5008}^{h}=k_{11}^{h} y_{13}\left(\frac{x_{13}+x_{14}}{y_{13}+y_{14}}\right)$ is the salt composition at the output of $\mathrm{TV}-5008$, and $k_{11}^{h}=\frac{z_{11}^{i-1}}{x_{11}}$ is the factor which relates the recursive concentration equation with the overall $\mathrm{NaCl}$ in line 11 . Hence, the salt composition at the input of the dehydration stage is estimated recursively, Eq. (6):

$$
z_{11}^{i-1}=\left(x_{11}-x_{31 R}\right)+x_{31 R}\left(\frac{z_{5006}^{s-1}}{x_{24}}\right)
$$

Furthermore, initial conditions must be considered. The salt composition regards to the output of the desalting stage is $z_{5006}^{s-1}=k_{19}^{s-1} x_{24}\left(\frac{x_{23}+x_{24}}{y_{23}+y_{24}}\right)$ where $k_{19}^{s-1}=z_{19}^{j-1}$. Moreover, the salt composition at the input of the desalting stage $z_{19}^{j-1}$ can be set as below, Eq. (7):

$$
z_{19}^{j-1}=k_{13}^{h^{\prime}-1}\left(x_{19}-x_{29 R}\right)+x_{29 R}\left(\frac{z_{5006}^{s-2}}{x_{24}}\right)
$$

where $z_{5006}^{s-2}=k_{19}^{s-2} x_{24}\left(\frac{x_{23}+x_{24}}{y_{23}+y_{24}}\right), k_{19}^{s-2}=k_{h^{\prime}-1}$ and $k_{h^{\prime}-1}=\frac{z_{h-1}}{x_{13}}$. Thus, the salt composition regards to the dehydration stage is initially expressed as $z_{h-1}=y_{13}\left(\frac{x_{13}+x_{14}}{y_{13}+y_{14}}\right)$. Henceforth, while many numbers of recursive equations are used, the convergence is achieved. Thus, the proposed algorithm to estimate the water and salts contents in Fig. 4 consists of:

1) Define the set of variables for: the overall $\mathrm{NaCl}$ concentration $\mathcal{X}$, the aqueous $\mathrm{NaCl}$ compositions $\mathcal{Y}$, the recursive concentrations of salt $\mathcal{Z}$ and the factors $\mathcal{K}$ which relates the recursive concentration equations.

2) Compute the salt composition at the input of the dehydration stage, Eq. (4).

3) Define the factor which relates the recursive concentration equation with the overall $\mathrm{NaCl}$ at the input of the desalting stage (line 19).

4) Compute the salt composition at the input of the desalting stage, Eq. (5).

5) Define the factor which relates the recursive concentration equation with the overall $\mathrm{NaCl}$ at the input of the dehydration stage (line 11).

6) The algorithm goes to step 2 using Eq. (6) until convergence is achieved.

7) Compute the salt composition regards to the output of the desalting stage, Eq. (7).

\section{SIMULATION RESULTS}

In this section, maximum liquid level, liquid level, and operating pressures and temperatures of vessels are compared with theoretical values. Additionally, to validate the accuracy of the model, the simulated results of the main flows are compared with taken data from a two-stage dehydration and desalting plant [33]. Finally, the behaviour of the plant in dynamic regime is evaluated after input load disturbances in salinity, water content and crude oil are encountered. 


\subsection{Modelling results}

Table VII shows that the dynamic requirements of the vessels are closed to the real values [33]. Moreover, Table VIII shows that the operating pressure and temperatures of the vessels are not far from those specified in [24, 33].

Table VII: Dynamic requirements comparison.

\begin{tabular}{|c|c|c|c|c|}
\hline \multirow{2}{*}{ Vessel } & \multicolumn{2}{|c|}{ Max. liquid level $(\mathrm{m})$} & \multicolumn{2}{c|}{ Liquid level $(\mathrm{m})$} \\
\cline { 2 - 5 } & Simulation & Real & Simulation & Real \\
\hline TV-5008 & 13.4154 & 13.556 & 13.0049 & $11.670-13.565$ \\
\hline FA-3020 & 3.444 & 3.505 & 2.455 & $1.52-3.505$ \\
\hline TV-5006 & 13.4154 & 13.556 & 13.0049 & $11.670-13.565$ \\
\hline
\end{tabular}

Table VIII: Operating pressure and temperatures comparison.

\begin{tabular}{|c|c|c|c|c|}
\hline \multirow{2}{*}{ Vessel } & \multicolumn{2}{|c|}{ Pressure $(\mathrm{kPa})$} & \multicolumn{2}{c|}{ Temperature $\left({ }^{\circ} \mathrm{C}\right)$} \\
\cline { 2 - 5 } & Simulation & Real & Simulation & Real \\
\hline TV-5008 & 94.045774 & 101.325 & 31.34 & 30 \\
\hline FA-3020 & 108.36348 & 101.325 & 48.86 & 49 \\
\hline TV-5006 & 111.89388 & 101.325 & 48.57 & 45 \\
\hline
\end{tabular}

\subsection{Dynamic mode results}

To prove the accuracy of the considered model, in Table IX the process simulated values such as crude oil flowrate, water content and salinity are compared with real values consulted in [22]. The results show that the simulated values approximate the operability of the real plant.

Table IX: Validation model for dehydration and desalting stage.

\begin{tabular}{|l|c|c|c|c|c|c|}
\hline \multirow{2}{*}{ Stage } & \multicolumn{2}{|c|}{ Crude oil load (barrels/day) } & \multicolumn{2}{c|}{ Water content $\left(\% \mathrm{H}_{2} \mathrm{O}\right)$} & \multicolumn{2}{c|}{ Salinity $(P T B)$} \\
\cline { 2 - 7 } & Simulation & Real & Simulation & Real & Simulation & Real \\
\hline Input process & 670,182 & 670,182 & 26 & 26 & 5,200 & 5,200 \\
\hline Output TV-5008 & 502,838 & 502,636 & 1.04 & 1 & 237 & 240 \\
\hline Input TV-5006 & 521,600 & 521,917 & 4.997 & 5 & 464.8 & 460 \\
\hline Output process & 498,046 & 498,431 & 0.4995 & 0.5 & 49.65 & 50 \\
\hline
\end{tabular}

Additionally, considering that the performance analysis of the system is an important issue to forecast the behaviour of the process [34], a series of simulated disturbances are applied to the plant (see Table X). Hence, the input crude oil is adjusted by the VLV-Crude, and the water and salt contents are regulated by the VLV-Water and VLV-Salt valves, respectively.

Table X: Input disturbances.

\begin{tabular}{|c|c|cl|}
\hline Disturbance & Input & \multicolumn{2}{|c|}{ Flow rates and composition } \\
\hline \multirow{2}{*}{ Crude oil } & $+25 \%$ & $600,000=>750,000$ & (barrels/day) \\
& $-25 \%$ & $600,000=>450,000$ & (barrels/day) \\
\hline \multirow{2}{*}{ Water content } & $+5 \%$ & $25=>30$ & $\left(\% \mathrm{H}_{2} \mathrm{O}\right)$ \\
& $-5 \%$ & $25=>20$ & $\left(\% \mathrm{H}_{2} \mathrm{O}\right)$ \\
\hline \multirow{2}{*}{ Salinity } & $+25 \%$ & $6000=>7500$ & $(P T B)$ \\
& $-25 \%$ & $6000=>4500$ & $(P T B)$ \\
\hline
\end{tabular}

As it can be seen in Fig. 5 a, increasing the input crude oil by $+25 \%$, the crude oil production is stabilized after $8.72 \mathrm{~h}$. Moreover, salinity in the output crude oil is out of the range for $10 \mathrm{~h}$. On the other hand, decreasing the input crude oil by $-25 \%$, Fig. 5 b, the water and salt contents are out of range for $1.1 \mathrm{~h}$ and $0.7 \mathrm{~h}$, respectively. This affects the crude oil quality and represents a significantly negative economic impact in its selling price. To avoid this, research on advanced control strategies must be implemented as in [35]. 

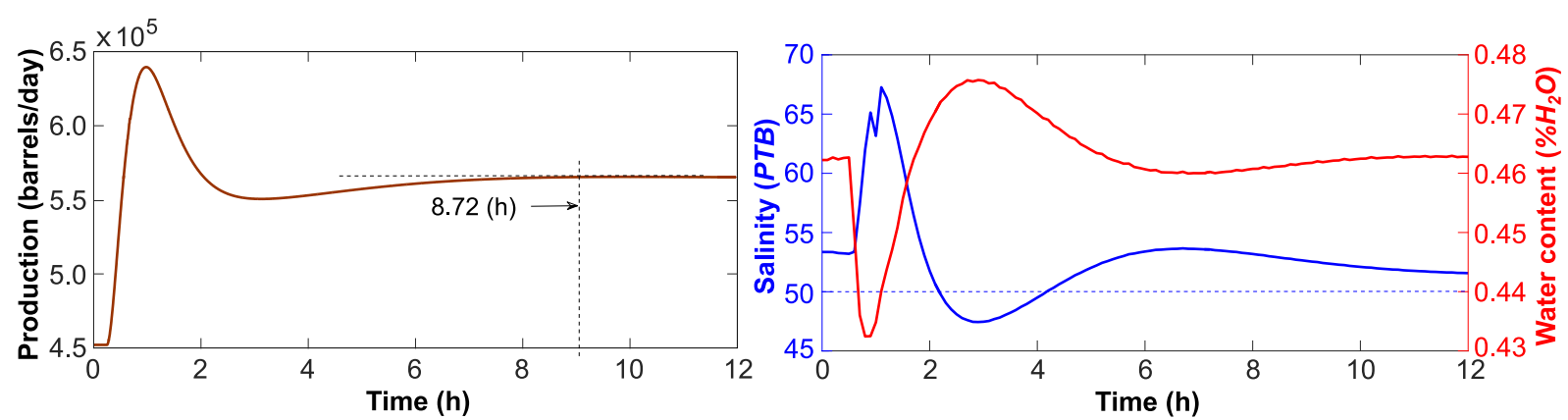

a)
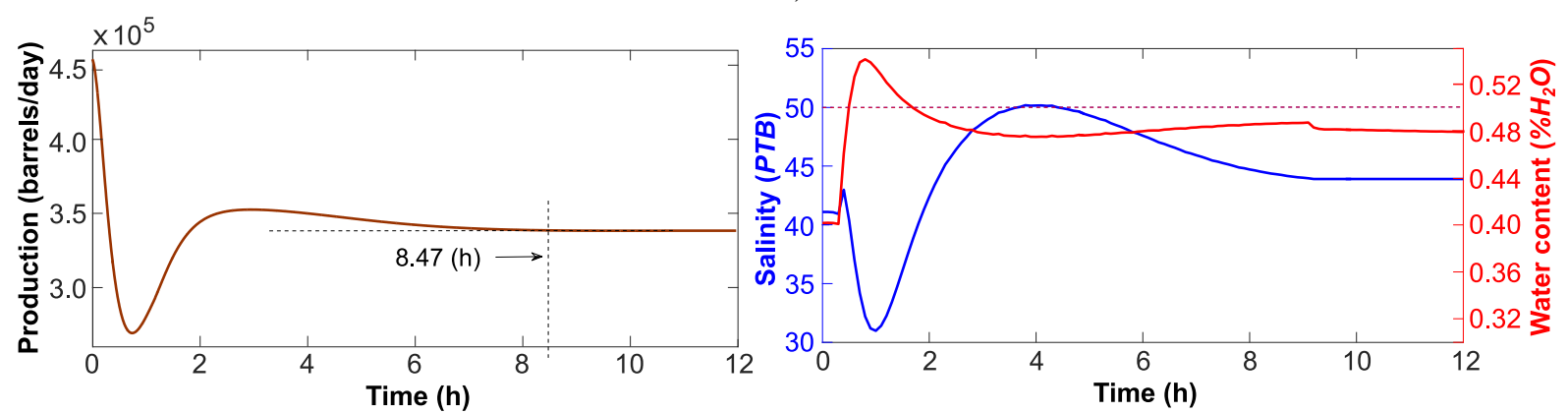

b)

Figure 5: Production and crude oil water-salt content under: a) $+25 \%$ input crude oil load disturbance, b) $-25 \%$ input crude oil load disturbance.

Fig. 6 a shows that increasing the input water feed by $+5 \%$, the crude oil production is reduced to 353,000 barrels/day, and the salinity is in range for $1.4 \mathrm{~h}$. Additionally, decreasing the input water content by $-5 \%$, Fig. $6 \mathrm{~b}$, the crude oil production is increased up to 401,400 barrels/day, and the salinity is out of the range after $1 \mathrm{~h}$. To avoid this, in real plants controllers are manually adjusted by plant operators [16].
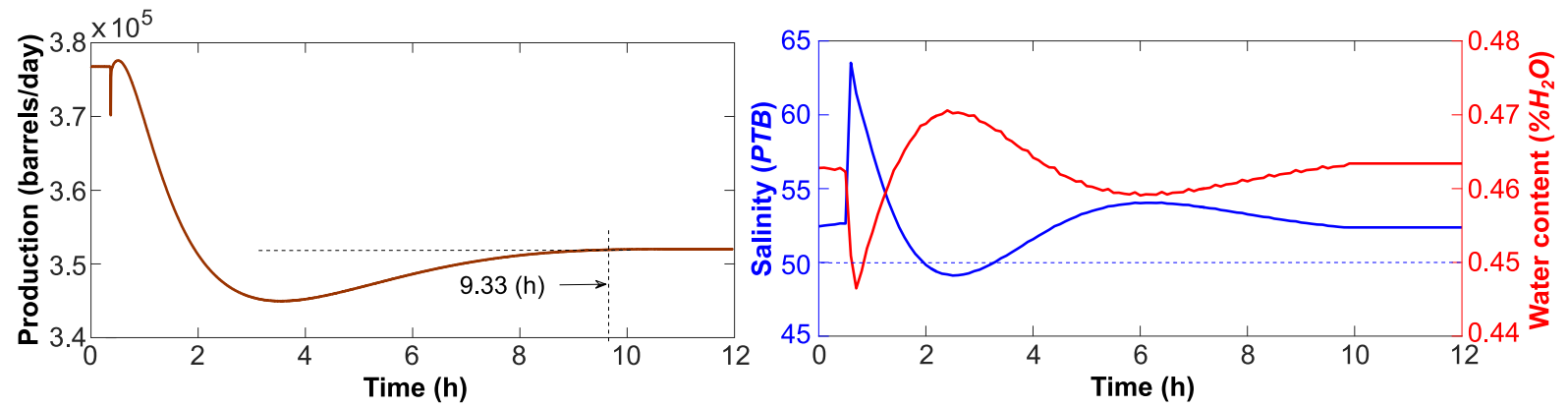

a)
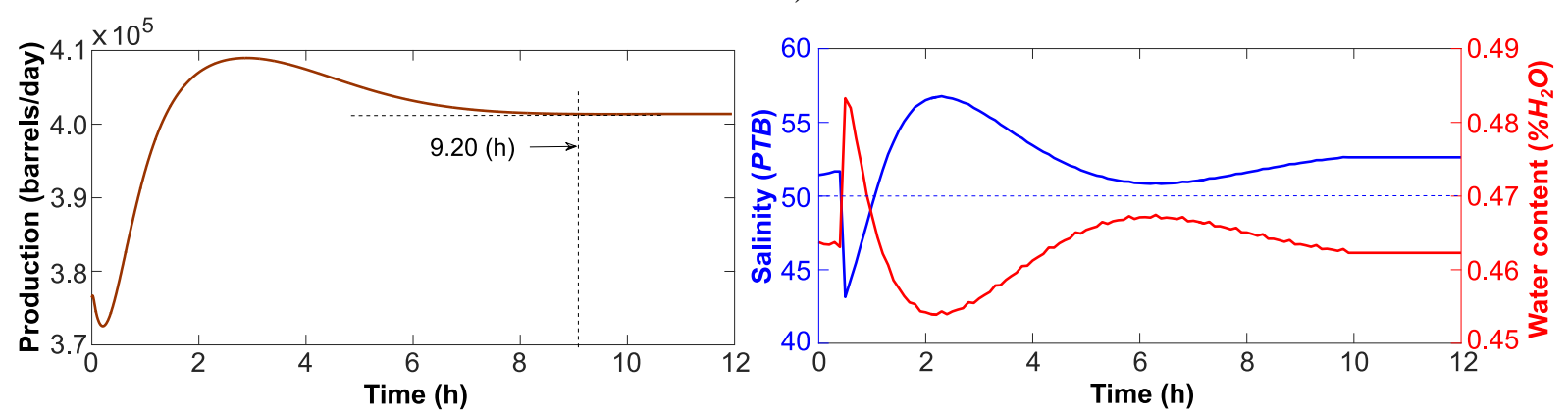

b)

Figure 6: Production and crude oil water-salt content under: a) $+5 \%$ input water content disturbance, b) $-5 \%$ input water content disturbance. 
In Fig. 7 a, increasing the input salinity feed by $+25 \%$, the crude oil production is reduced to 375,000 barrels/day and stabilized after $10.8 \mathrm{~h}$. Moreover, the water and salt contents fulfil the international specifications. On the other hand, the crude oil production is increased when the input salinity feed is reduced by $+25 \%$, Fig. $7 \mathrm{~b}$. In this case, water and salt contents in the crude oil diverges due to the fixed set points in the controllers [35].
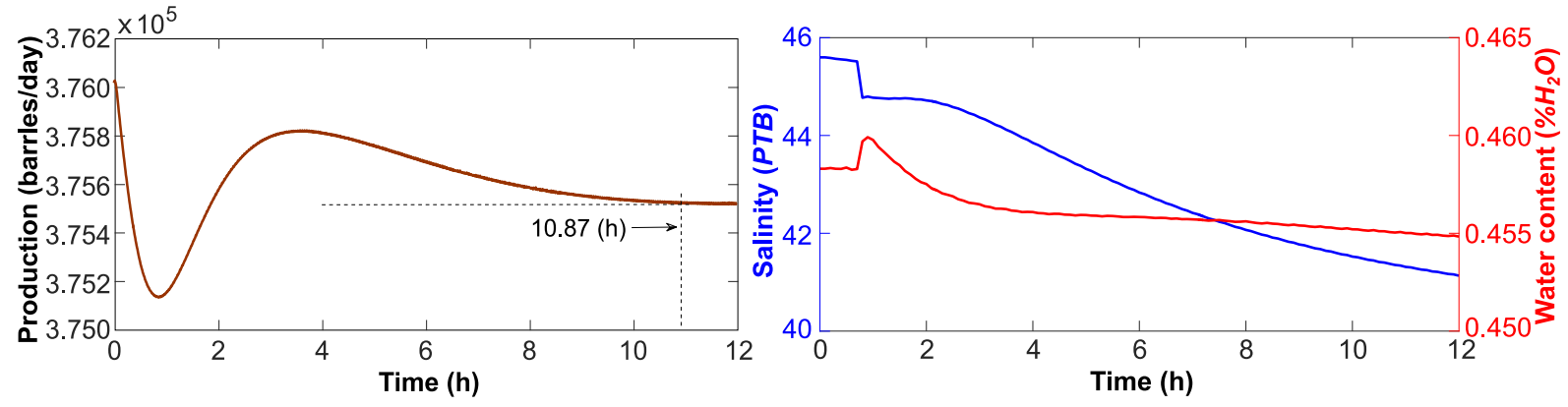

a)
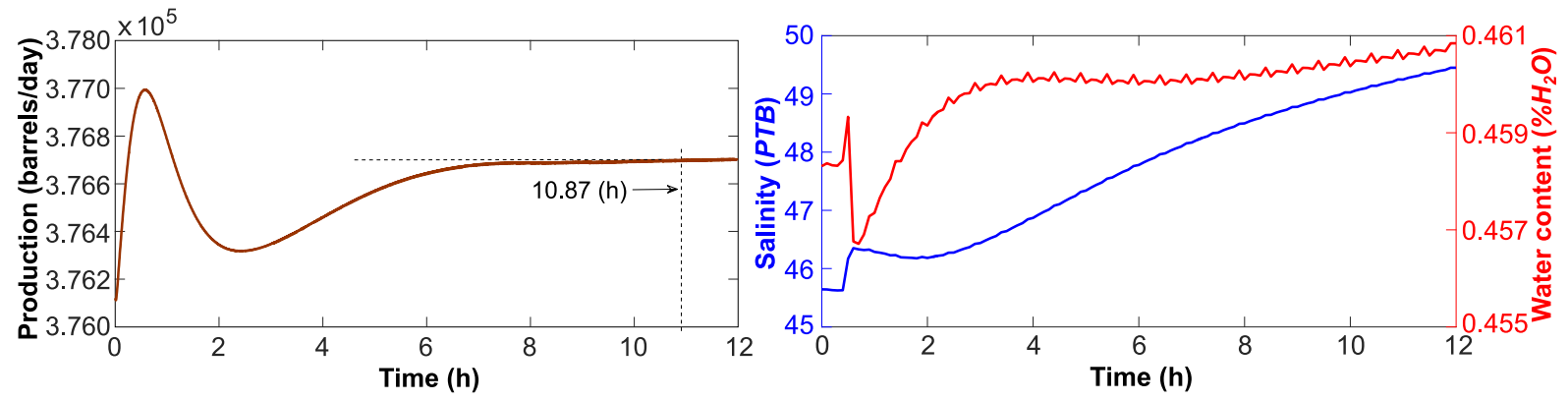

b)

Figure 7: Production and crude oil water-salt content under: a) $+25 \%$ input salinity disturbance, b) $-25 \%$ input salinity disturbance.

\section{CONCLUSION}

This work presents a methodology for simulating a complete dehydration and desalting crude oil plant using Aspen HYSYS ${ }^{\circledR}$ environment in dynamic mode. Considering a characterized heavy crude oil and based on a deep literature review, process units are carefully designed to generate a rigorous and accurate dynamic simulation. Moreover, a specially tailored simulation procedure for predicting the water and salt contents in crude oil under real operating conditions is developed. The dynamic requirements of the vessels and the main flows along the process are compared with actual data and theoretical values specified in the research field, which validates the accuracy of the model. Thus, the present work enables a better understanding of the process behaviour under real operating conditions. In addition, no study in the open literature has presented such a procedure. Henceforth, it serves as an open scientific platform to develop a variety of routine operational tasks, such as process control, process optimization, condition monitoring, fault diagnosis, performance analysis, and performance improvement. On the other hand, the modelling strategy and the proposed tailored procedure can be extended to simulate any dehydration and desalting crude oil plants even when other process simulators (i.e. Aspen Plus, Unisim, and Pro II) are used.

\section{ACKNOWLEDGEMENT}

This work is supported by the Tecnologico de Monterrey and the National Council for Science and Technology (CONACYT), México. The authors also want to show great thanks to the School of Engineering and Sciences for its support for the development of this work. 


\section{REFERENCES}

[1] Abdel-Aal, H. K.; Zohdy, K.; Abdelkreem, M. (2018). Waste management in crude oil processing: crude oil dehydration and desalting, International Journal of Waste Resources, Vol. 8, No. 1, Paper 1000326, 4 pages, doi:10.4172/2252-5211.1000326

[2] Kiani, H.; Moradi, S.; Soulgani, B. S.; Mousavian, S. (2013). Study of a crude oil desalting plant of the national Iranian south oil company in Gachsaran by using artificial neural networks, International Journal of Environmental and Ecological Engineering, Vol. 7, No. 12, 1015-1018

[3] Sotelo, D.; Favela-Contreras, A.; Lozoya, C.; Beltran-Carbajal, F.; Dieck-Assad, G.; Sotelo, C. (2019). Dynamic simulation of a crude oil distillation plant using Aspen Hysys, International Journal of Simulation Modelling, Vol. 18, No. 2, 229-241, doi:10.2507/IJSIMM18(2)465

[4] Hosseinpour, F.; Ghader, S.; Rahimpour, M. R.; Bagheri, H. (2019). Modification of an industrial crude oil desalting unit by electric mixing to improve the dehydration efficiency, Journal of Chemical Technology and Metallurgy, Vol. 54, No. 1, 124-134

[5] Mahdi, K.; Gheshlaghi, R.; Zahedi, G.; Lohi, A. (2008). Characterization and modeling of a crude oil desalting plant by a statistically designed approach, Journal of Petroleum Science and Engineering, Vol. 61, No. 2-4, 116-123, doi:10.1016/j.petrol.2008.05.006

[6] Elhaddad, E.; Abdel-Raouf, M. E. S. (2013). New model to eliminate salts from sarir crude oil: a case study, International Journal of Engineering research and Science \& Technology, Vol. 2, No. 4, 182-189

[7] Aryafard, E.; Farsi, M.; Rahimpour, M. R.; Raeissi, S. (2016). Modeling electrostatic separation for dehydration and desalination of crude oil in an industrial two-stage desalting plant, Journal of the Taiwan Institute of Chemical Engineers, Vol. 58, 141-147, doi:10.1016/j.jtice.2015.06.028

[8] Aryafard, E.; Farsi, M.; Rahimpour, M. R. (2015). Modeling and simulation of crude oil desalting in an industrial plant considering mixing valve and electrostatic drum, Chemical Engineering and Processing: Process Intensification, Vol. 95, 383-389, doi:10.1016/j.cep.2015.06.011

[9] Gonçalves, D. D.; Martins, F. G.; de Azevedo, S. F. (2010). Dynamic simulation and control: application to atmospheric distillation unit of crude oil refinery, Proceedings of the $20^{\text {th }}$ European Symposium on Computer Aided Process Engineering, 445-451

[10] Kim, S. F.; Usheva, N. V.; Moyzes, O. E.; Kuzemnko, E. A.; Samborskaya, M. A.; Novoseltseva, E. A. (2014). Modelling of dewatering and desalting processes for large-capacity oil treatment technology, Procedia Chemistry, Vol. 10, 448-453, doi:10.1016/j.proche.2014.10.075

[11] Rajesh, K.; Shivappa, D. (2013). Adopting distributed control system to control desalting process in petroleum refinery, International Journal of Emerging Technology and Advanced Engineering, Vol. 3, No. 10, 575-580

[12] Fajobi, M. A.; Loto, R. T.; Oluwole, O. O. (2019). Corrosion in crude distillation overhead system: a review, Journal of Bio- and Tribo-Corrosion, Vol. 5, No. 3, Paper 67, 9 pages, doi:10.1007/ s40735-019-0262-4

[13] Loto, R. T. (2017). Study of the corrosion behaviour of S32101 duplex and 410 martensitic stainless steel for application in oil refinery distillation systems, Journal of Materials Research and Technology, Vol. 6, No. 3, 203-212, doi:10.1016/j.jmrt.2016.11.001

[14] Liu, Z.; Karimi, I. A. (2018). Simulating combined cycle gas turbine power plants in Aspen HYSYS, Energy Conversion and Management, Vol. 171, 1213-1225, doi:10.1016/ j.enconman.2018.06.049

[15] Askari, A.; Karimi, H.; Rahimi, M. R.; Ghanbari, M. (2012). Simulation and modeling of catalytic reforming process, Petroleum \& Coal, Vol. 54, No. 1, 76-84

[16] Sotelo, D.; Favela-Contreras, A.; Sotelo, C.; Jiménez, G.; Gallegos-Canales, L. (2017). Design and implementation of a control structure for quality products in a crude oil atmospheric distillation column, ISA Transactions, Vol. 71, No. 2, 573-584, doi:10.1016/j.isatra.2017.08.005

[17] Karimi, H.; Askari, A.; Mansouri, E. (2014). Simulation and sensitivity analysis for heavy linear paraffins production in LAB production plant, Polish Journal of Chemical Technology, Vol. 16, No. 4, 87-94, doi:10.2478/pjct-2014-0075

[18] Liu, Z.; Karimi, I. A. (2019). Simulation of a combined cycle gas turbine power plant in Aspen HYSYS, Energy Procedia, Vol. 158, 3620-3625, doi:10.1016/j.egypro.2019.01.901 
[19] Ekwonu, M. C.; Perry, S.; Oyedoh, E. A. (2013). Modelling and simulation of gas engines using Aspen HYSYS, Journal of Engineering Science and Technology Review, Vol. 6, No. 3, 1-4, doi:10.25103/jestr.063.01

[20] AspenTech (2017). Aspen HYSYS V9 Help - Peng-Robinson calculation methods, Aspen Technology, Inc., Bedford

[21] Cani, X.; Malollari, I.; Beqiraj, I.; Manaj, H.; Premti, D.; Liçi, L. (2016). Characterization of crude oil from various oilfields in Albania through the instrumental analysis, Journal of International Environmental Application and Science, Vol. 11, No. 2, 223-228

[22] Garcia, E. C. (2012). Control Adaptativo Predictivo Para la Otimización de un Proceso de Deshidratación y Desalado de Crudo Maya, PhD Thesis, Technologico de Monterrey, Monterrey

[23] Reyes, S. S.; Gaviria, C. A. (2019). Hierarchical control scheme for optimal setting of setpoints in a threephase separator of a crude treatment train, Entre Ciencia e Ingeniería, Vol. 13, No. 26, 5967, doi:10.31908/19098367.1163

[24] Manning, F. S.; Thompson, R. E. (1995). Oilfield Processing Volume Two: Crude oil, PennWell Books, Tulsa

[25] Evans, F. L. (1971). Equipment Design Handbook: For Refineries and Chemical Plants, Gulf Publishing Company, Houston

[26] Jin, G.; Liu, Z. (2017). Computational flow dynamic simulation of micro flow field characteristics drainage device used in the process of oil-water separation, Geofluids, Vol. 2017, Paper 8916313, 9 pages, doi: $10.1155 / 2017 / 8916313$

[27] Asuaje Tovar, M.; Benítez, N.; Quintero, D.; Gaviria, M. R.; Díaz, E.; Chacón, C. (2018). Improvements in the dehydration process of heavy crude oil, using CFD: case study campo QuifaColombia, Proceedings of the ASME $20185^{\text {th }}$ Joint US-European Fluids Engineering Division Summer Meeting, Paper V002T09A027, 10 pages, doi:10.1115/FEDSM2018-83442

[28] Doust, A. M.; Shahraki, F.; Sadeghi, J. (2012). Simulation, control and sensitivity analysis of crude oil distillation unit, Journal of Petroleum and Gas Engineering, Vol. 3, No. 6, 99-113, doi:10.5897/JPGE

[29] Nitsche, M.; Gbadamosi, R. (2017). Demister design, Nitsche, M.; Gbadamosi, R. (Eds.), Practical Column Design Guide, Springer, Cham, doi:10.1007/978-3-319-51688-2_11

[30] Laleh, A. P.; Svrcek, W. Y.; Monnery, W. D. (2012). Design and CFD studies of multiphase separators - a review, The Canadian Journal of Chemical Engineering, Vol. 90, 1547-1560, doi: $10.1002 /$ cjce. 20665

[31] Tvrdon, L.; Fedorko, G. (2020). Usage of dynamic simulation in pressing shop production system design, International Journal of Simulation Modelling, Vol. 19, No. 2, 185-196, doi:10.2507/IJSIMM19-2-494

[32] Bhanot, V.; Dhumane, R.; Petagna, P.; Cioncolini, A.; Iacovides, H.; Ling, J.; Aute, V. (2019). Development of a numerical tool for dynamic simulations of two-phase cooling systems, International Journal of Simulation Modelling, Vol. 18, No. 2, 302-313, doi:10.2507/IJSIMM18(2)476

[33] PEMEX (2011). Anuario Estadístico 2011 (02 Exploración y Producción), 12-27, Petróleos Mexicanos, Ciudad de México

[34] Kim, B. S.; Kim, T. G. (2019). Cooperation of simulation and data model for performance analysis of complex systems, International Journal of Simulation Modelling, Vol. 18, No. 4, 608-619, doi:10.2507/IJSIMM18(4)491

[35] Sotelo, C.; Favela-Contreras, A.; Sotelo, D.; Beltran-Carbajal, F.; Cruz, E. (2018). Control structure design for crude oil quality improvement in a dehydration and desalting process, Arabian Journal for Science and Engineering, Vol. 43, No. 11, 6579-6594, doi:10.1007/s13369$\underline{018-3360-6}$ 